\title{
繰返し複合応力を受ける構造用鋼材の履歴挙動に関する基礎実験 EXPERIMENTAL STUDY ON THE HYSTERESIS BEHAVIOR OF STRUCTURAL STEEL UNDER MULTI-AXIAL CYCLIC LOADING
}

\author{
松本由香*1, 鄭 景 洙*2, 山田哲*3 \\ Yuka MATSUMOTO, Kyungsoo CHUNG and Satoshi YAMADA
}

\begin{abstract}
The aim of this study is investigating the hysteresis behavior of structural steel subjected multi-axial loading. For this purpose, the loading equipment and cylindrical specimens were manufactured. The loading equipment provided various loading paths, such as uni-axial loading, simultaneous loading of axial force and torsion, and alternating axial force and torsion. Uniform multi-axial stresses were generated in the cross-section of cylindrical specimens. The stress-strain relations were measured and the hysteresis behavior was examined in term of effective stress-effective strain.
\end{abstract}

Keywords : stress-strain relation, hysteresis behavior, multi-axial stress, hysteresis model 応力-歪関係、履歷挙動、多軸応力、履歴モデル

1. 序

鋼材の応力䄳関係は、鋼構造物の挙動を予測する上で最も基本的 な情報である。建築構造物においては、部材の塑性変形能力に期待 した終局耐震設計が行われること、接合部などで多軸応力状態が生 じること、地震時に三次元的且つランダムな繰返し力が作用するこ となどを考慮すると、繰返し複合応力に対して適用可能な鋼材の構 成則を構築することが求められる。

複合応力下の構成則は、等方硬化則 ${ }^{11} 、$ 移動硬化則 ${ }^{2.3) 、 又 は こ れ ~}$ らを組み合わせたモデル4がー一般的である。更に、これらのモデルの 予測精度を改善させるため、複数の降伏曲面によるモデルも提案さ

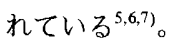

建築分野においては、大きな塑性䄳に対してランダムな繰返し力 が加わることから、多様な載荷経路を想定する必要がある。単軸応 力状態での履歴挙動については実験データが豊富であり、既往の履 歴モデル8.910なとによって良好な予測值が得られるようになっている。 多軸応力状態については、実験の実施が困難であることから実験デ 一夕は少なくなるが、既に履歴モデルを構築するための研究が行わ れている

一方、鋼部材の履歴曲線を骨格曲線、バウシンガー一部、弾性除荷 部に分解して扱う手法が提案されている ${ }^{14)}$ 。これには、骨格曲線とバ
ウシンガー部では損傷に対する寄与が異なる、という着想が背䀠に ある。この概念を鋼材の履歴モデルに適用し、骨格曲線とバウシン ガー部に対して各々の形状を定義するモデルが提案されている ${ }^{8.10 .15}$ なと)。これらは実験式として構築されたものであるが、損傷に笴与す る度合いによって履歴曲線を分割することを試みている点で注目に 值する。分割方法の妥当性については議論の余地があるが、損傷の 度合いに注目して現象を捉えることは鋼材の終局挙動を理解する上 で有意義であり、破壊メカニズムを解明するためにも示唆するもの があると思われる。

上記の方針に基く履歴モデルのうち、文献 15 ではバウシンガ一部 をバイリニアで近似したモデルを提案している。このモデルは、軸方 向繰返し試験の結果に基いて導かれたものであり、簡潔ながらも、 部材解析において荷重変形関係やエネルギ一吸収量などを良好に予 測できたことが報告されている。更に、文献 16 ではせん断応力に対 しても同様のモデルが適用可能であることが確認されている。

本研究では、鋼材の複合応力下の履歴挙動について検討する。先 ず、載荷経路をパラメータとして円筒形試験片の軸方向載荷、权じ り載荷試験を行い、その結果を報告する。更に、実験デー夕に基い て降伏曲面を設定し、文献 15 のモデルを複合応力状態に適用できる よう拡張したモデルを提案する。
*1 横浜国立大学大学院工学研究院 助手 ·博士 (工学)

*2 東京工業大学大学院 大学院生・修士 (工学)

*3 東京工業大学建築物理研究センター 助教授・博士 (工学)
Research Assoc., Faculty of Eng., Yokohama National Univ., Dr. Eng. Graduate Student, Tokyo Institute of Technology, M. Eng.

Assoc. Prof., Structural Engineering Research Center, Tokyo Institute of Technology, Dr. Eng. 


\section{2. 複合応力載荷試験}

\section{1 試験片}

使用鋼材は SS400 材、SM490A 材として入手した市場品であり、 それそれれ 1 ロットずつの材料を用いている。各鋼材の JIS4 号金属材 料試験片による引張試験結果を表 1 に示す。表 1 によると、SM490A 材として入手した鋼材は、実際には降伏強さの規格を満足していな いが、ここでは便宜上 SM490A と表記する。

複合応力下の履歴則について調査するためには、一様な多軸応力 状態を実験的に再現する必要がある。そこで、試験片は図 1 に示す ような中空円筒状とし、これに軸力と权じりモーメメンをかけるこ とによって、試験片断面に一様な軸方向応力とせ九断応力が作用す るように計画している。図中、材軸方向長さ $25 \mathrm{~mm}$ の平行部が試験部 である。

\section{2 セットアップ}

四2に試験片のセットアッブを示す。試験片の一端は二分力荷重計 を介して反カフレームムに固定され、他端は載何用门盤に接続されて いる。載荷用网盤は試験片に軸力及び权じりモ・メントを伝達する ためのものであり、材軸方问の並進及び材軸回りの回転が叮能であ

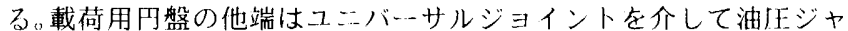
ッキに接続されて拐り、この油任ジャッキによって軸方问載荷を行

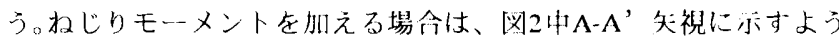
に、載荷用円盤に固分した鋼棒の先端に鈖直方问の強制変位を年え る。

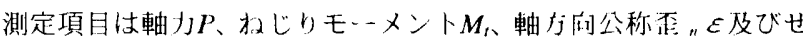
ん断歪とである。P及びMは四2中の分力何重計により計測する。

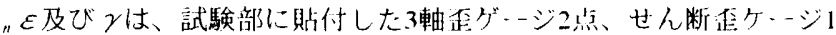
点加求める。

\section{3 載荷経路}

載荷経路は単軸応力シリース、多軸応力シリースス、複合交番載荷 シリーズの 3 シリーズに大別できる。

(1) 単軸応力シリーズ

軸方向応力のみ若しくはせん断応力のみを、恭なる載荷パター-ン で作用させる。表2に試験片一覧を示す。

載荷パ夕ーンは、単調載荷、両側漸増䨛振幅載荷、両側三段歪振 幅載荷、片側漸增歪振幅載荷、片側骨格曲線載街の 5 つである。載 荷パ夕ーンの模式図を図3に示す。片側骨格曲線載荷では、先ず止負 両側に0.5\%〜 1\%程度の歪振幅を与える。この後、吏に大きな塑性歪 を一方向に与え、載荷方向を反転させる。他方には過去の最大応力 を上回らないレバルまで載荷し、再び載荷方向を反転させる。この 過程を繰り返すと、一方向の骨格曲線が他方に対して卓越する。

(2) 多軸応力シリーズ

本シリーズでは、先ず引張、せん断いずれかに載荷した後、この ときの応力または歪（初期応力又は初期歪と表記）を保持した状態 で他方（軸方向、せん断方向のうち初期応力として導入しなかった 方）の応力を変動させる。変動応力は、単軸応力シリーズと同様に 載荷パターンを変化させている。表3に試験片一覧を示す。

(3) 複合交番載荷シリーズ

引張、せん断のいずれか一方に塑性履歴を与えて除荷した後、他 方に載荷を行う。試験片一覧を表4に示す。表中には載荷手順及び
各々の段階で与える目標歪の值を示している。表中、加力後に残留 歪を残した状態で他方向に載荷するもの（図4(a)）を「除荷」、目 標歪を与えた後に反対方向に載荷し、残留歪を除去してから他方向 に載荷するもの(図4(b))を「原点復帰」と表記している。

表1 使用鋼材の機械的性質

\begin{tabular}{|c|c|c|c|c|}
\hline & 降伏強さ & 引張強さ & 降伏比 & 一様伸び \\
\hline & {$[\mathrm{MPa}]$} & [MPa] & & {$[\%]$} \\
\hline SS400 & 301 & 462 & 0.65 & 22,8 \\
\hline SM490A & 317 & 519 & 0.61 & 20.7 \\
\hline
\end{tabular}
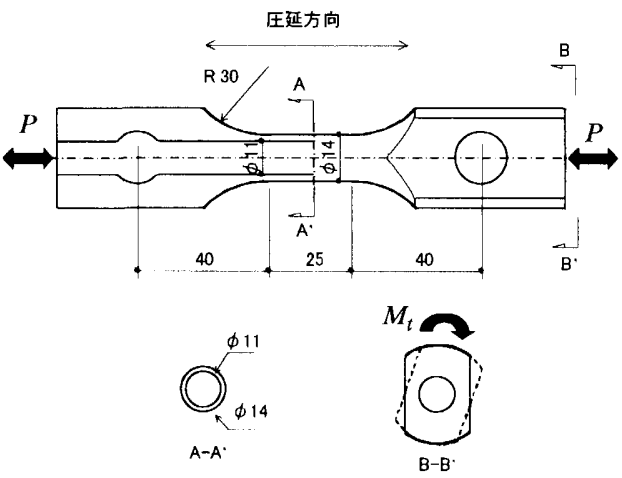

図1 試験片形状

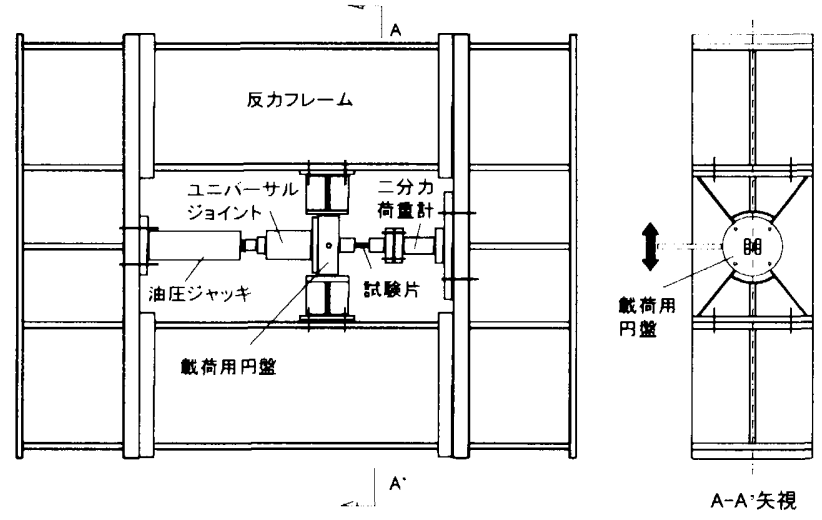

図2 セットアップ

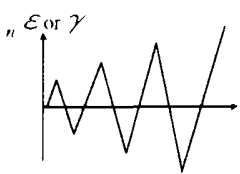

(a) 両側漸増歪振幅

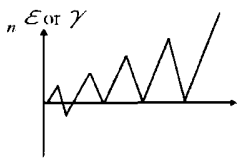

（c）片側漸増歪振幅 (b) 両側二段歪振幅

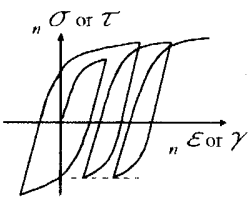

（d）片側骨格曲線

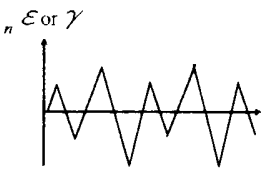

図3 載荷パターン

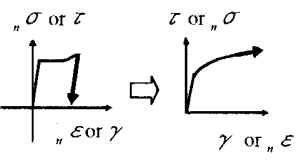

（a）除荷
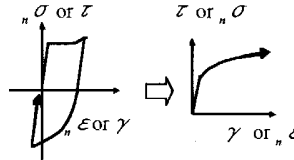

（b）原点復懤
図4 残留歪の有無 
試験片名称は以下の規則に従う。

単軸応力シリーズおよび多軸応力シリーズ

鋼材 - 載荷順序 - 初期応力 (又は歪) 一載荷パ夕ーン

$$
\text { SS : SS400 A : 軸方向応力 }
$$$$
\text { SM : SM490A S : せ九断応力 }
$$

複合交番載荷シリーズ

$$
\begin{aligned}
& \text { 鋼材 - 載荷順序 - 通し番号 } \\
& \text { SS : SS } 400 \\
& \text { SM : S S 軸方向応力 } \\
& \text { SM }
\end{aligned}
$$

\section{4 応力及び歪の換算}

軸方向公称応力 $\sigma$ 。は次式によって得られる。

$$
\begin{aligned}
{ }_{n} \sigma & =P / A \\
P & : \text { 軸力(引張を正) } \\
A & : \text { 試験部原断面積 }
\end{aligned}
$$

公称歪 ${ }_{n}$ とは歪ゲージによる計測値を用いる。ここで、体積一定を

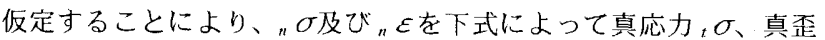
モにに換算する。

$$
\begin{aligned}
& { }_{t} \sigma=\left(1+{ }_{n} \varepsilon\right)_{n} \sigma \\
& { }_{r} \varepsilon=\ln \left(1+{ }_{n} \varepsilon\right)
\end{aligned}
$$

せん断応力 $\boldsymbol{\tau}$ は次式によって得られる。

$$
\tau=M_{t} /\left(2 \cdot t \cdot A^{\prime}\right)
$$

$$
\begin{aligned}
& M_{t}: \text { 小じりモーメント(初期載荷側を正) } \\
& t: \text { 試験部板厚 } \\
& A^{\prime}: \text { 試験部板厚中心線で囲まれる円の面積 }
\end{aligned}
$$

せん断歪 ケは歪ゲージ計測值による。

全試験片の履歴ルーブを同一変数で評価するため、得られたデー 夕を相当応力 $\sigma$ 的び相当歪 $e q$ に換算する。 $e q \sigma$ 不式で表される。

$$
e q=\sqrt{\sigma^{2}+3 \tau^{2}}
$$

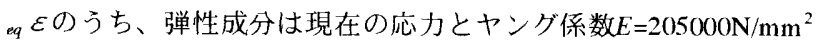
及びせん断弹性係数 $G=79000 \mathrm{~N} / \mathrm{mm}^{2}$ から求められる。塑性成分は下式 によって求められる。

$$
e q \varepsilon_{p}=\sum_{i} \sqrt{{ }_{t} \varepsilon_{p, i}{ }^{2}+\frac{\gamma_{p, i}{ }^{2}}{3}}
$$

\begin{tabular}{|c|c|c|c|}
\hline 試験片 & 材料 & 忍力 & 載荷パターン \\
\hline SS-A-0-0 & SS400 & 軸方向 & 単調 \\
\hline SS-A-0-1 & SS400 & 軸方向 & 両側漸增歪振幅 \\
\hline SS-A-0-3 & SS400 & 軸方向 & 片側漸增歪振幅 \\
\hline SS-S-0-0 & SS400 & せん断 & 単調 \\
\hline SS-S-0-1 & SS400 & せん断 & 両側漸增歪振幅 \\
\hline SS-S-0-2 & $\$ S 400$ & せん断 & 両側二段歪振幅 \\
\hline SS-S-0-3 & SS400 & せん断 & 片側漸增歪振幅 \\
\hline SS-S-0-4 & $S S 400$ & せん断 & 片側骨格曲線 \\
\hline SM-A-0-0 & SM490A & 軸方向 & 単調 \\
\hline SM-A-0-1 & SM490A & 軸方向 & 両側漸增歪振幅 \\
\hline SM-A-0-3 & SM490A & 軸方向 & 片側漸増垔振幅 \\
\hline SM-A-0-4 & SM490A & 軸方向 & 片側骨格曲線 \\
\hline SM-S-0-0 & SM490A & せん断 & 単調 \\
\hline SM-S-0-1 & SM490A & せん断 & 兩側漸增歪振幅 \\
\hline SM-S-0-2 & SM490A & せん断 & 兩側二段丕振幅 \\
\hline$S M-S-0-3$ & SM490A & せん断 & 片側漸増歪振幅 \\
\hline SM-S-0-4 & SM490A & せん断 & 片側骨格曲線 \\
\hline
\end{tabular}

${ }_{t} \varepsilon_{p, i}, t \gamma_{p, i}:$ 第iサイクル降伏点から除荷点又は現在の歪点までの 軸方向塑性歪增分及びせ九断塑性歪増分

\begin{tabular}{|c|c|c|c|c|}
\hline 試験片 & 材料 & 初期応力陉 & 変動応力 & 載荷バターン \\
\hline SS-SA-50-0 & SS400 & $\tau=50 \mathrm{MPa}$ & 軸方向 & 単調 \\
\hline SS-SA-50-3 & SS400 & $\tau=50 \mathrm{MPa}$ & 軸方向 & 片側漸增歪振幅 \\
\hline SS-SA-100-0 & $S S 400$ & $\tau=100 \mathrm{MPa}$ & 軸方向 & 単調 \\
\hline SS-SA-100-1 & SS400 & $\tau=100 \mathrm{MPa}$ & 軸方向 & 両側渐增歪振幅 \\
\hline SS-SA-1-0 & $5 S 400$ & $\gamma=1 \%$ & 軸方向 & 单調 \\
\hline SS-SA-3-0 & 55400 & $\gamma=3 \%$ & 軸方向 & 単調 \\
\hline SS-AS-150-0 & $S S 400$ & $\sigma=150 \mathrm{MPa}$ & せん断 & 単調 \\
\hline SS-AS-150-1 & SS400 & $\sigma=150 \mathrm{MPa}$ & せん断 & 両側漸増歪振幅 \\
\hline SS-AS-100-1 & $S S 400$ & $\sigma=100 \mathrm{MPa}$ & せん断 & 両側漸增歪振幅 \\
\hline SS-AS-200-1 & SS400 & $\sigma=200 \mathrm{MPa}$ & せん断 & 両側漸增丕振幅 \\
\hline SM-SA-50-0 & SM490A & $\tau=50 \mathrm{MPa}$ & 軸方向 & 単調 \\
\hline SM-SA-50-3 & SM490A & $\tau=50 \mathrm{MPa}$ & 軸方向 & 片側漸增歪振幅 \\
\hline SM-SA-100-0 & SM490A & $\tau=100 \mathrm{MPa}$ & 軸方向 & 単調 \\
\hline SM-SA-100-1 & SM490A & $\tau=100 \mathrm{MPa}$ & 軸方向 & 兩側漸増歪叚幅 \\
\hline SM-SA-1-0 & SM490A & $\gamma=1 \%$ & 軸方向 & 単調 \\
\hline SM-SA-3-0 & SM490A & $\gamma=.3 \%$ & 軸方向 & 単調 \\
\hline SM-AS-150-0 & SM490A & $\sigma=150 \mathrm{MPa}$ & せん断 & 単調 \\
\hline SM-AS-150-1 & SM490A & $\sigma=150 \mathrm{MPa}$ & せん断 & 両側漸增丕振幅 \\
\hline SM-AS-100-1 & SM490A & $\sigma=100 \mathrm{MPa}$ & せん断 & 両側濑增歪振幅 \\
\hline SM-AS-200-1 & SM490A & $\sigma=200 \mathrm{MPa}$ & せん断 & 両側漸增歪振幅 \\
\hline
\end{tabular}

本論文では、第iサイクル載荷開始点からの歪增分のうち、弹性歪 成分を除去して残留歪を求め、これらの值を ${ }_{t} \varepsilon_{p, i}, \gamma_{t, i}$ として(6)式

\begin{tabular}{|c|c|c|c|c|c|c|c|}
\hline 試験片 & 材料 & \multicolumn{2}{|l|}{ (1) } & \multicolumn{2}{|l|}{ (2) } & \multicolumn{2}{|l|}{ (3) } \\
\hline SS-SA-1 & SS 400 & せ九断 & $\gamma=1 \%$ 除荷 & 弓張 & 破断まで & & \\
\hline SSSA.2 & $\operatorname{SS} 400$ & せん断 & $\gamma=3 \%$ 除荷 & 引張 & 破断まで & & \\
\hline SS-SA-3 & $\operatorname{SS} 400$ & せん断 & $\gamma=1 \%$ 原点復㴆 & 張 & 破断まで & & \\
\hline SS-SA-4 & $\operatorname{SS} 400$ & せん断 & $\gamma=3 \%$ 原点復㷌 & 弓脹 & 破断まで & & \\
\hline SS-ASA-1 & SS 400 & 弓張 & $\varepsilon=2 \%$ 除荷 & せん断 & $\gamma=6 \%$ 除荷 & 弓涱 & 破断 \\
\hline SS-ASA-2 & SS 400 & 張 & $\varepsilon=4 \%$ 除荷 & せん断 & $\gamma=6 \%$ 除荷 & & \\
\hline SS-ASA-3 & SS 400 & 張 & $\varepsilon=4 \%$ 原点復帰 & せ九断 & $\gamma=6 \%$ 除荷 & & \\
\hline SM-SA-1 & SM 490A & せ人断 & $\gamma=3 \%$ 除荷 & 引㤢 & 破断まで & & \\
\hline SM-SA-2 & $S M 490 A$ & せん断 & $\gamma=1 \%$ 原点復帰 & 马脹 & 破断まで & & \\
\hline SM-SA-3 & SM 490A & せん断 & $\gamma=3 \%$ 原点復㷌 & 弓張 & 破断まで & & \\
\hline SM-ASA-1 & SM $490 \mathrm{~A}$ & 引張 & $\varepsilon=2 \%$ 原点復㷌 & せん断 & $\gamma=6 \%$ 除荷 & 弓張 & 破断 \\
\hline
\end{tabular}
に代入している。

\section{3. 履歴挙動の評価}

\section{1 材料の等方性}

単調載荷した試騃片および表 1 中に示した素材引張試験について、

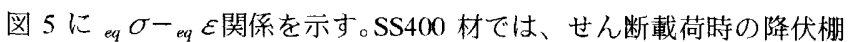

付近における応力が引張載荷時の值をやや下回っている。しかし、 ${ }_{e q} \sigma-_{e q} \varepsilon$ 関係の全体的な傾向は、いずれの鋼材においても引張載荷 時の曲線とせん断載荷時の曲線が一致しており、使用鋼材は等方性 材料と見なすことができよう。

表2 単軸応カシリーズの試験片一覧

表3 多軸応カシリーズの試験片一覧

表4 複合交番載荷シリーズの試験片一算 


\section{2 相当応力ー相当歪による履歴曲線}

\section{2 .1 履歴曲線の分解}

図6に、SS-AS-150-1の実験結果を例示する。図中(a)には、軸方向 及びせん断方向について、各々の応力歪曲線を示す。図中(b)には、 試験終了までの全履歴デー夕を相当応力一相当歪に換算して得られ る履歴曲線を実線で示している。この履歴曲線から、過去の最大応 力を上回る毎に線分を抽出して繋いでいくことによって得られた曲 線を骨格曲線と定義する。その他の部分はバウシンガ一部及び弾性 除荷部に分解される。図7に履歴曲線の分解方法を示す。図中の記号 のうち、 $\Delta_{e q} \varepsilon_{s}$ 骨格曲線開始点から除荷点までの区間における相 当塑性歪増分、 $\Sigma \Delta_{e q} \varepsilon_{s}$ は骨格曲線における累積歪、 $\Delta_{e q} \varepsilon_{B}$ は各サ イクルのバウシンガー部開始点から骨格曲線に復帰するまでの相当 塑性歪増分である。

図6(b)に、得られた情格曲線を太実線で示す。図中には、引張試験 結果を破線で示しているが、両者は概孙・致している。

\section{2 .2 骨格曲線の形状}

3.2.1の方法で抽出した骨格曲線と引張試験結果を罒8に比較して 示す。骨格曲線は引張試験結果と良い对応を示しており、載荷シリ 一ズや鋼種による傾向の違いは認められなかった。

\subsection{3 バウシンガー部の形状}

骨格曲線における歪履歴が累積するに従って、バウシンガー一部は 軟化し、次の悄格曲線に復帰するまでに要する塑性走增分が増加す

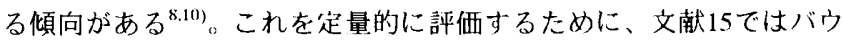
シンガー部をエネルギー一吸収に関して等洒なバイリニア型でモデル 化し、剛性変化点の応力とバウシンガ一部における塑性昰增分を調 查している。図9にモデル化の方法を示す。モデルの第一折線の㴊性 は、弹性剛性と等しい。図中、q $\sigma_{B}$ はバウシンガ一部終点の応力（次 の愲格曲線に復帰するときの応力）、 $\alpha_{B}$ は然 $\sigma_{B}$ に対する㓮性変化点 の応力の比を表す係数、 $\triangle_{e q} \varepsilon_{B}$ は次の骨格曲線に復帰するまでに要 する塑性歪増分である。ここで、本実験について $\Delta_{e q} \varepsilon_{B}$ 及び $\alpha_{B}$ を求 め、バウシンガー一部の形状について検討する。

バウシンガーが現れる毎に、その時点までに棵積した $\Sigma \Delta_{\text {eq }} \varepsilon_{s}$ と 当該バウシンガ一部の $\Delta_{e q} \varepsilon_{B}$ を求め、耐者の関係を調査した結果を 図10に示す。図中、単軸応力シリーズを白抜き記号、多軸応力シリ 一ズを塗りつぶし記号及び編掛け記号で表す。同一試騒片のデー一 に着目すると、両者は概权線形となっており、これは文献15の結果 と符合する。単軸応力シリーズのデータは、傾き $2 / 30$ 直線の近傍に 分布している。文献15では両者の傾きは1/3であり、本論文の1/2にな っているが、これは骨格曲線の定義の相違に起因するもので、実騃 デー夕の本質的な相違によるものではない。つまり、文献15では引 張側と圧縮側において各々骨格曲線が定義されるため、骨格曲線で の累積相当塑性歪が本論文の定義による值に対して約 2 倍になるた めである。多軸応力シリーズのデータでは、初期応力の増加に伴っ $\tau \Delta_{e q} \varepsilon_{B}-\Sigma \Delta_{e q} \varepsilon_{s}$ 関係の傾きが低下する傾向が見られる。

図11に $\alpha_{B}$ と $\Delta_{e q} \varepsilon_{B}$ の関係を示す。凡例は図10と同様である。文 献 15 では $\Delta_{e q} \varepsilon_{B}$ に関わらず $\alpha_{B}=2 / 3$ としており、本論文の単軸応力シ リーズの $\alpha_{B}$ も概ね $2 / 3$ となっている。多軸応力シリーズでは、 $\alpha_{B}$ は 初期応力の増加に伴って高くなる傾向が見られる。

複合交番載荷シリーズについて、得られた履歴曲線を図 12 に例

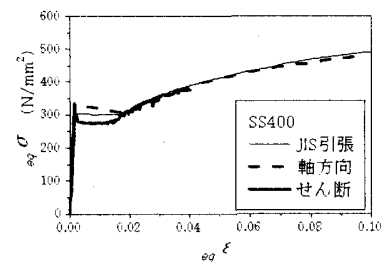

(a) SS400

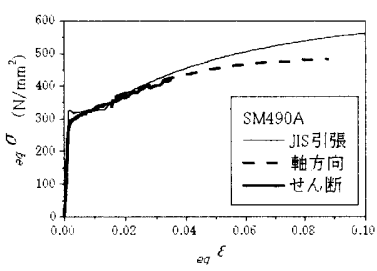

(b) SM490A
図 5 単調載荷時の応力歪曲線
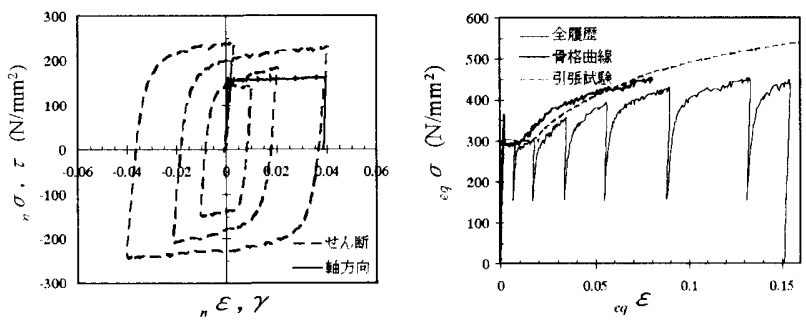

(a) 軸方向成分とせん断方向成分 (b) 相当応力一相当歪 図6 多軸応力状態における履歴曲線(SS-AS-150-1)

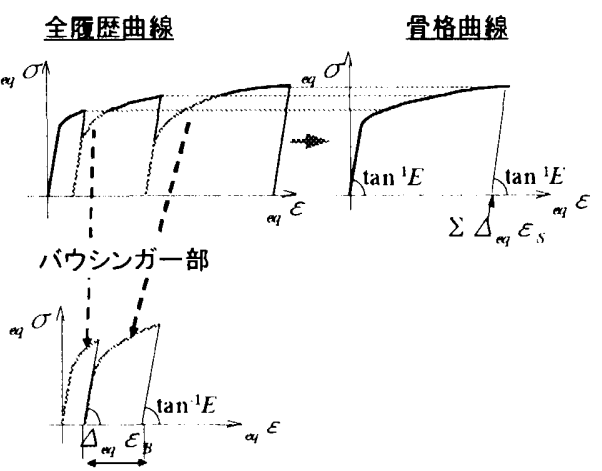

図7履歷曲線の分解

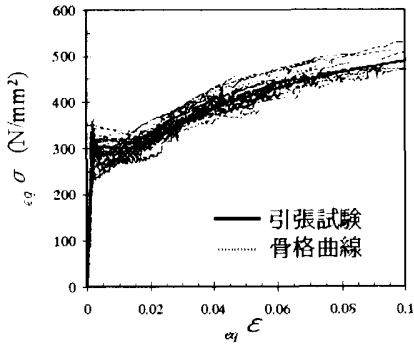

(a) SS400

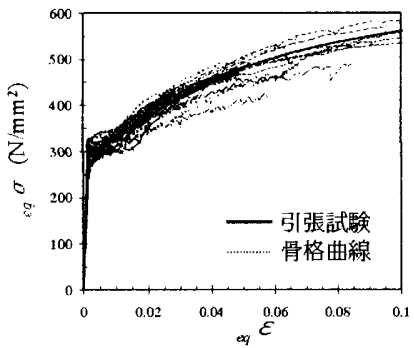

(b) SM490A

\section{図8骨格曲線と引張試験との比較}

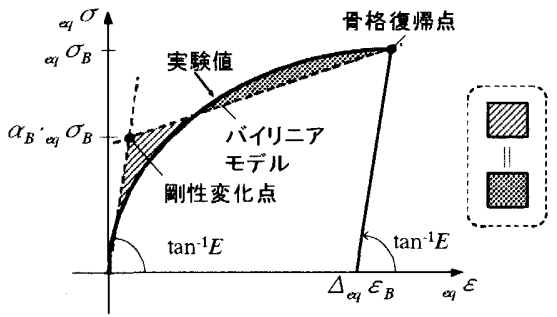

図9 バウシンガー部のモデル化

示する。全履歴曲線の形状を見ると、せ九断塑性履歴を受けた直後 の引張載荷時と、軸方向塑性履歴を受けた直後のせん断載荷時には、 直前の除荷点近傍まで高い剛性を保持しており、バウシンガー部に おける軟化部がほとんど見られない。 


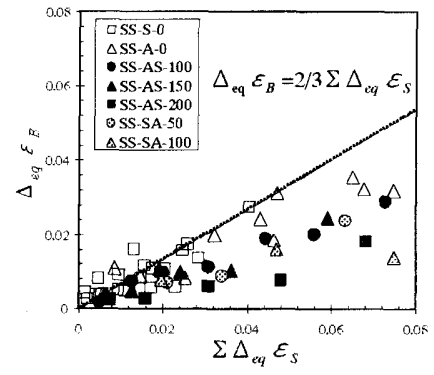

(a) $S S 400$

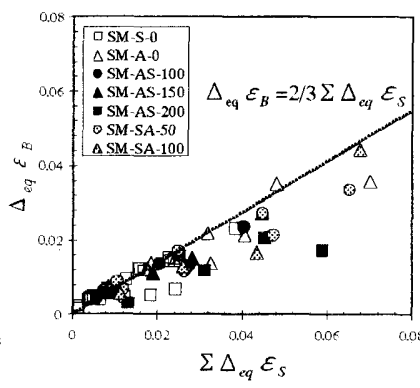

(b) SM490A
図 10 バウシンガー部塑性歪増分と骨格曲線累積塑性歪の関係

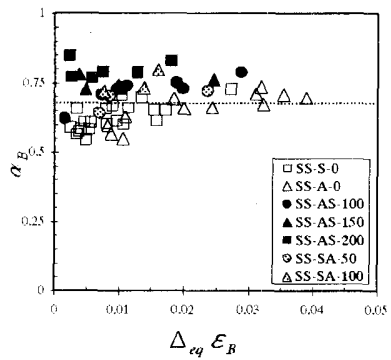

(a) $S S 400$

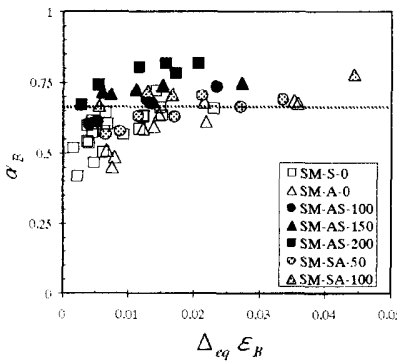

(b) SM490A

图 11 バウシンガー部における剛性変化点応力と塑性歪増分の関係

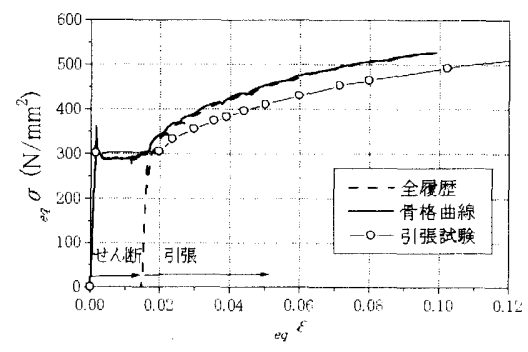

(a) SS-SA-2

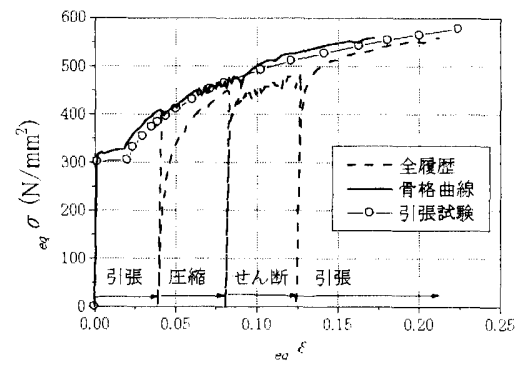

(b) SS-ASA-3

図 12 複合交番載荷シリーズの履歴曲線

\section{4. 複合応カ下における履歴モデル \\ 4.1 基本方針}

文献15の履歷モデルでは、履歴曲線を骨格曲線、バウシンガー部、 弾性除荷部に竹解し、骨格曲線開始点やバウシンガー部剛性変化点 の決定方法を提示している。ここでは、これらの状態変化が生じる 条件を降伏曲面の形で定義することにより、既往のモデルを複合応 力状態に拡張する。

モデルの設定に際して、先ず単軸応力下において実騃デー夕と整 合するように降伏曲面を定義し、得られた降伏曲面がこれ以外の載
荷経路に対しても矛盾しないことを確認する、という方針を採った。 履歴モデル全般に適用する仮定及び設定する降伏曲面は以下の通 りである。

(1) 初期降伏条件はVon Misesの条件に従う。

(2) 骨格曲線又はバウシンガ一部で降伏曲面が拡大する際、応力増 分のうちの軸方向成分及びせ九断方向成分はRadial Return 法 ${ }^{17)}$ を使って求図13に手順を示す。

(3) 塑性ひずみ増分の方向は降伏曲面の法線方向に一致する。

(4) 応力空間において、骨格曲線降伏曲面、バウシンガ一部降伏曲 面を設定する。更に、バウシンガー部降伏曲面の位置および大 きさを決定するための補助的な曲面として、内接曲面を設定す る。

(5)次のサイクルで骨格曲線に復帰する塑性ひずみ位置を表すた め、塑性昰空間に执いて骨格曲線復帰曲面を設定する。

\section{2 骨格曲線のモデル化}

骨格曲線降伏曲面は等方硬化則に従って拡大だけを考慮する。相 当応力一相当歪による骨格曲線の形状は、単調引張試験による応力 ひずみ曲線に一致すると仮定する。このとき、塑性ポテンシャルF は下式によって表される。

$$
\begin{aligned}
& F=\frac{3}{2} \sigma_{i j}{ }^{\prime} \sigma_{i j}{ }^{\prime}=\bar{\sigma}^{2} \\
& \sigma_{i j}{ }^{\prime}: \text { 偏差応力 } \\
& \bar{\sigma}: \text { 当該応力点における相当応力 }
\end{aligned}
$$

また、骨格曲線における降伏曲面の桩大に伴い、塑性歪空間上の 骨格曲線復帰曲面が移動、拡大する。これは、弾性除荷が生じた後 に、次の骨格曲線に復㷌するときの相当塑性ひずみ位置を表すもの である。現在の歪点に打ける復帰曲線の法線方向は歪增分ベクトル

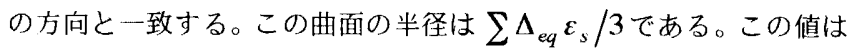
3.2.3で述べた実験結果に基いて決定したものである。

四14(a)に、応力が骨格曲線上にあるときの降伏曲面を図示する。

\section{3 バウシンガー部のモデル化}

バウシンガー部の降伏曲面の位置と大きさを決定するため、先ず バウシンガー部の内接曲面を設定する。内接曲面は骨格曲線降伏曲 面と同様に等方硬化則に従う。その半径は、3.2.3の実験結果に従つ て骨格曲線降伏曲面の2/3とし、塑性ポテンシャルは下式によって表 される。

$$
F=\frac{3}{2} \sigma_{i j}{ }^{\prime} \sigma_{i j}{ }^{\prime}=\left(\frac{2}{3} \bar{\sigma}\right)^{2}
$$

バウシンガー部降伏曲面は、現在の応力点を通り、且つ現在の応 力点と応力空間の原点を通る直線上で内接曲面に接する曲面として 定義される。バウシンガ一部降伏曲面は、塑性域（骨格曲線、バウ シンガー部塑性域の両者）で相当応力が上昇するときに変化し、弾 性除荷部にあるときは変化しないものとする。これらの条件から、 バウシンガ一部降伏曲面では、移動・拡大・縮小が考虑される。塑 性ボテンシャルは下式によって表される。

$$
\begin{aligned}
& F=\frac{3}{2}\left(\sigma_{i j}{ }^{\prime}-\alpha_{i j}{ }^{\prime}\right) \cdot\left(\sigma_{i j}{ }^{\prime}-\alpha_{i j}{ }^{\prime}\right) \\
& \alpha_{i j}{ }^{\prime}: \text { 降伏曲面中心の偏差応力 }
\end{aligned}
$$


バウシンガー部で降伏曲面が桩大する際の剛性は、相当応力増分

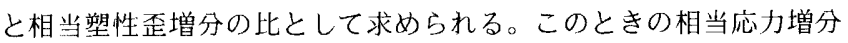
は、現在の応力点での相当応力と骨格曲線降伏曲面の半径との差分 に相当する。また、塑性歪増分は、現在の歪点と骨格曲線復帰曲面

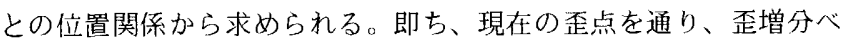
クトルと平行な直線が骨格曲線復帰曲面と交差する点を求め、この 点と現在のひずみ点の距離として塑性ひずみ増分を求める.

図14(b)に、応力点がバウシンガー部にあるときの降伏曲面を図示 する。

\section{4 載荷経路の影響}

本モデルの降伏曲面は、単軸応力下での履歴曲線と整合するよう 定めたものである。一方、3.2.3で述べたように、多軸応力シリーズ、 及び複合交番載荷シリーーズでは、単軸応力シリースズに対してバウシ ンガ一部における $\alpha_{B}$ が高くなり、 $\Delta_{\text {叫 }} \varepsilon_{F}$ が低くなる傾向が確認され た。この傾向は、前述のように設定された降伏曲面、䄳曲面によっ て、以下のように再現される。

載荷方向の変化によって弾性除荷部に人った後、态力点が応力空 間の原点を通る淔線にをを移動ずると、相当忘力が $\sigma_{0} \cdot 2 / 30$ 位置でバ ウシンガー部降伏曲面に到達する。この他の絓路を辿る場命、例えば 本実験の多軸总ノシリーーズや複合父番載荷シリーズのような載修経 路を辿る場合には、相当芯力が $\sigma_{0} \cdot 2 / 3$ を回可住㯰でバウシンガー

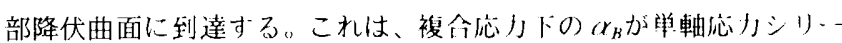
ズに比ベて高くなったことと符合寸るる。

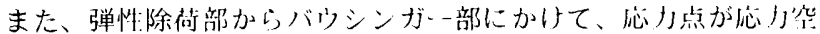

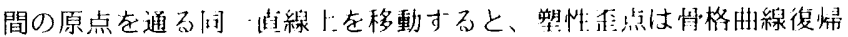
曲面の原点を通る古線上を移動才る。この場命、次の性格曲線に到

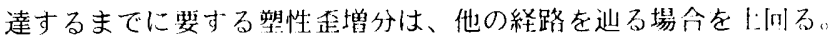
これは、複合念力下の $\Delta_{e q} \varepsilon_{b i}$ 少単軸忍力シリーズに比バて低くなっ たことと符合する。

以上、定性的な傾问について、本モデルが多軸忍ノシリーーズ及び 複合交番載荷シリーズの寒䮠結果と矛盾しないことを確認した。

\section{5 実験結果との対応}

\subsection{1 履歴曲線の比較}

単軸応力シリーズについて、前述の履䠂モデルによる履歴曲線予 測值と実験值を図15(a)〜(d)に示す。眓中、実験値を○で示し、予測 值を実線で示す。実験時には歪制御で載荷したため、予測値を求める 際には実騟值と等しい歪増分を与え、これに対応する応力予测値を 計算している。更に、文献16の履歴モデルによる予測值を破線で示 す。本論文のモデルでは文献16のモデルに比べて応力を若干高く評 価しているが、実騃値との対応は概ね良好である。

多軸応力シリーズについて、履歷モデルによる履歴曲線予測值と 実験值を比較するる。予測值を求める際には、軸方向及びせん断方向 の応力・歪のうち、実験での制御パラメ一夕の值を履歴モデルに代 入している。得られた結果を図16(a)〜(e)に示す。図中には、軸方向 及びせん断方向について各々の応力歪曲線を求めたものと、応力空 間又は歪空間に拀ける軌跡を示している。応力歪曲線によると、本 論文のモデルは履歴曲線の形状を良好に近似している。しかし、歪 空間における軌跡を兒ると、制御パラメータとしなかった方の歪に

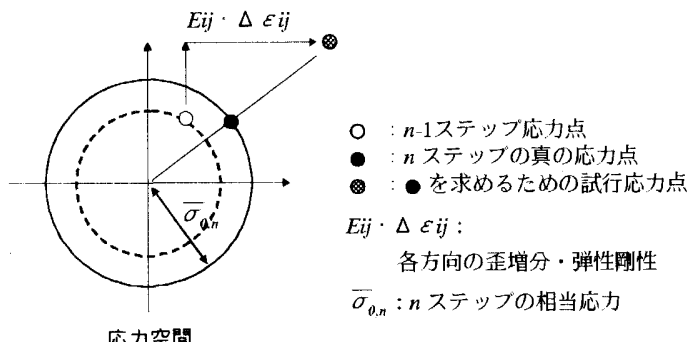

图13 Radial Return法 ${ }^{17}$

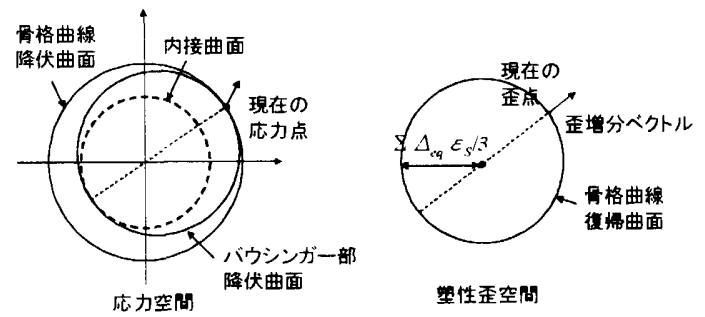

（a）応が襾格曲線上にある場合

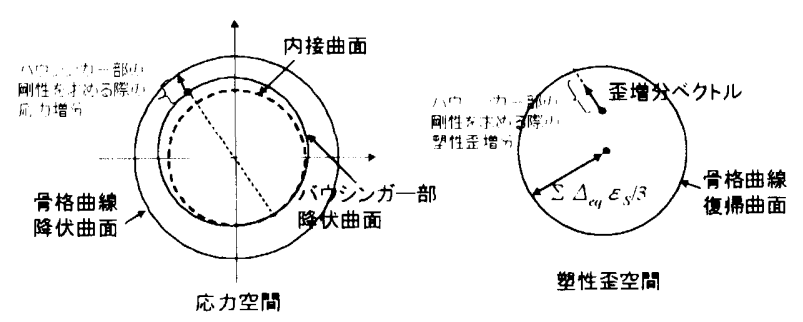

（b）応カがパウシンガー部塑性域にある場合 図14降伏曲面の設定

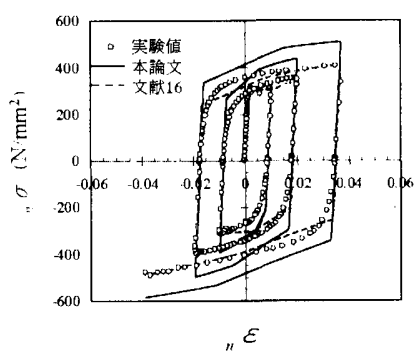

(a) SS-A-0-1

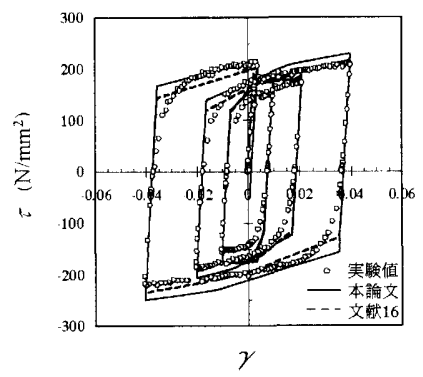

(c) $S S-S-0-1$

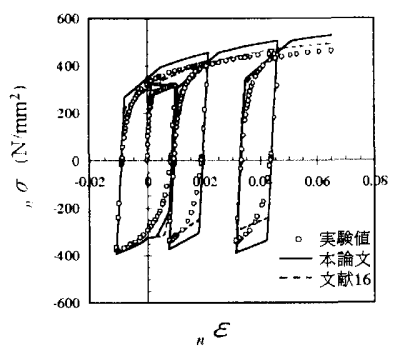

(b) $S M-A-0-4$

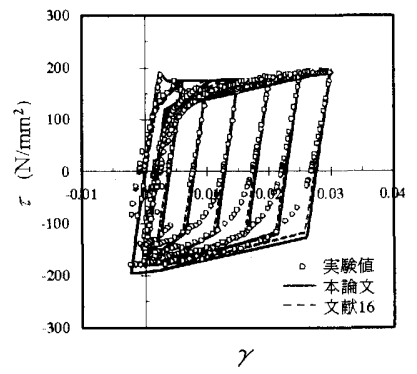

(d) $\mathrm{SS}-\mathrm{S}-0-3$
図15 単軸方向応力下における履歴曲線と履歴モデルとの比較 

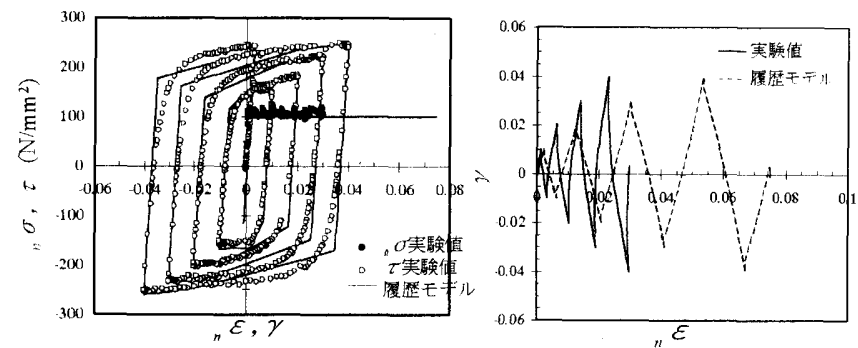

(a) SS-AS-100-1
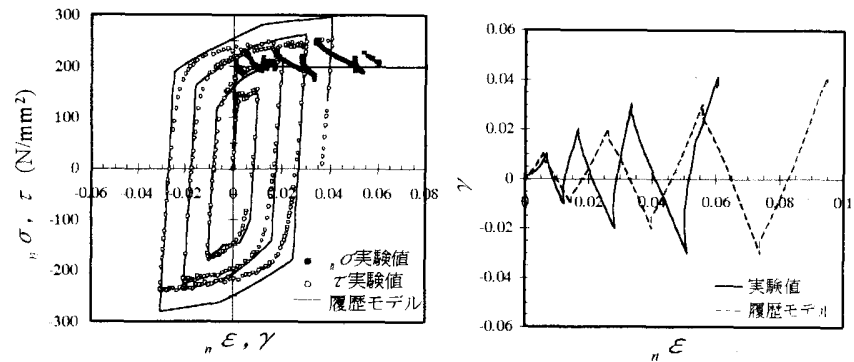

(b) $\mathrm{SM}-\mathrm{AS}-200-1$
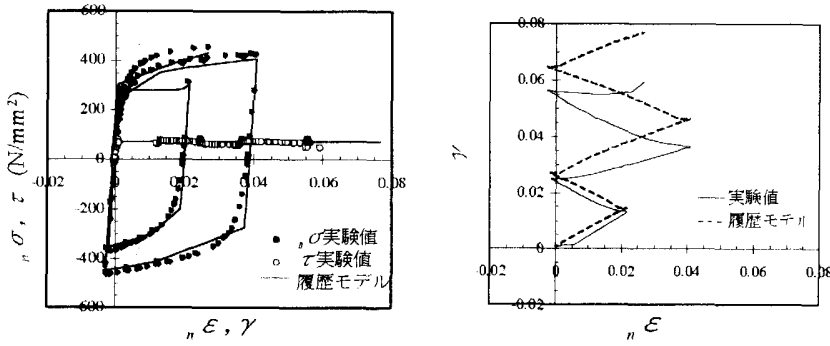

(c) $\mathrm{SS}-\mathrm{SA}-50-3$
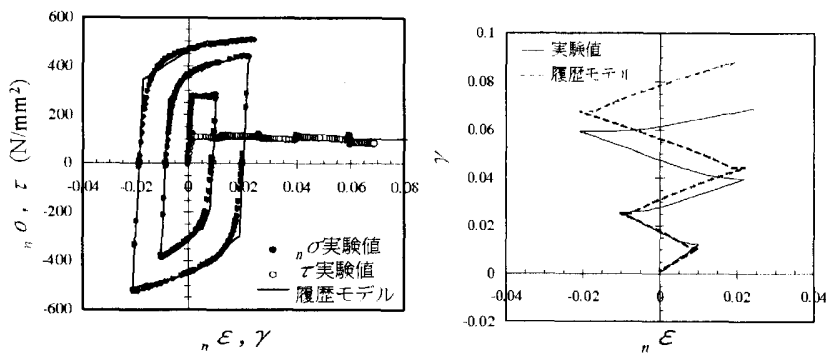

(d) $S M-S A-100-1$
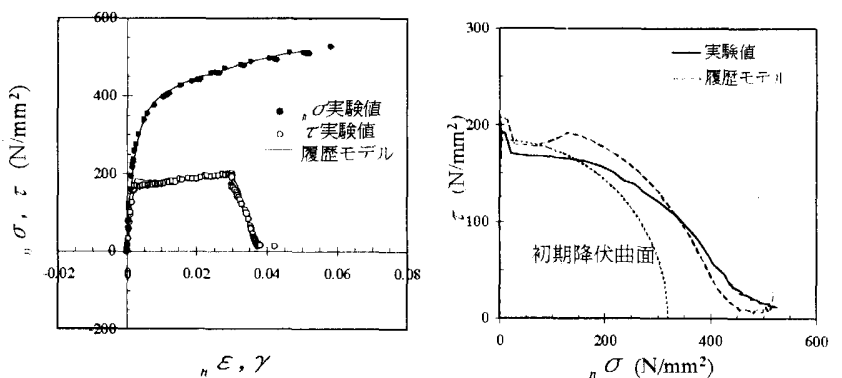

(e) $\mathrm{SM}-\mathrm{SA}-3-0$

図 16 多軸応カシリーズにおける履歴曲線と履歴モデルの比較

ついては、予測値が実験値を上回っている。特に、図16中(a)(b)に示 されるように、初期応力として軸方向応力を導入した場合の ${ }_{n}$ とにつ いて、誤差が大きくなる傾向がある。図16(e)は、制御パラメー夕を 軸方向歪およびせん断歪とした試験片のものであり、図中には応力 空間における軌跡を示している。履歴モデルによる予測值は実験に おける軌跡を再現できている。

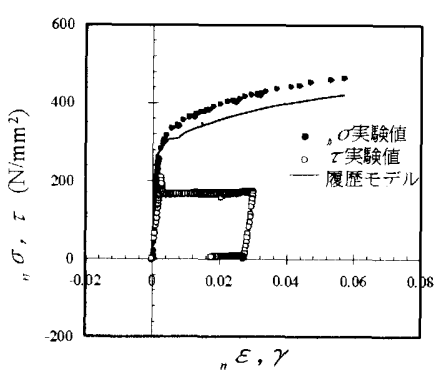

(a) SS-SA-2

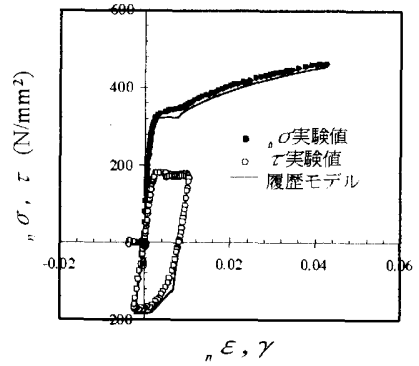

(c) $\mathrm{SM}-\mathrm{SA}-2$

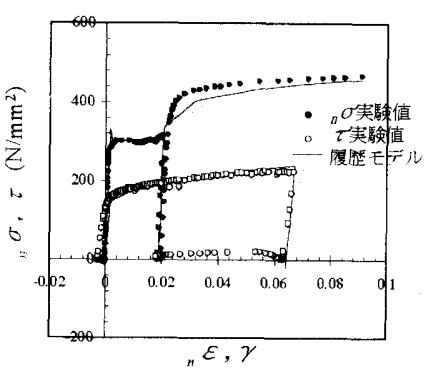

(b) SS-ASA-1

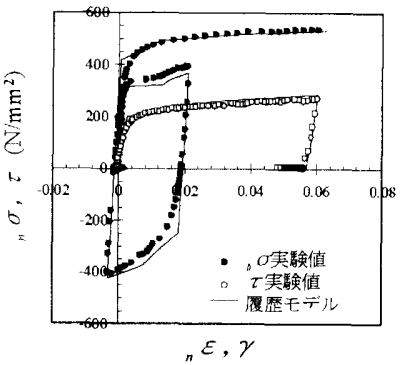

(d) SM-ASA-1
図17 複合交番載荷シリーズの履歴曲線と履歴モデルの比較

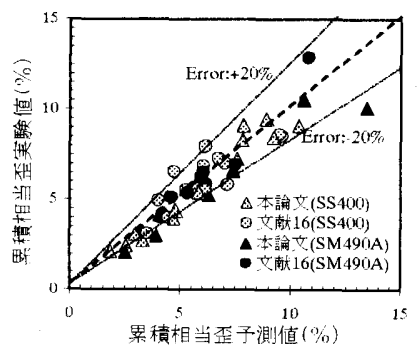

(a) 単軸応力

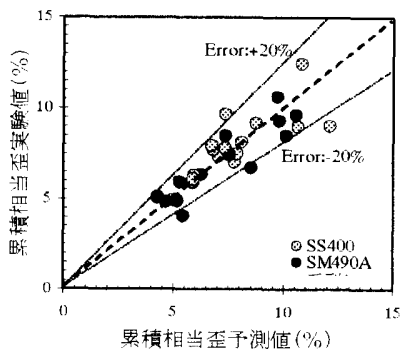

(b) 多軸応力及び複合交番
図18 骨格曲線の累積相当歪

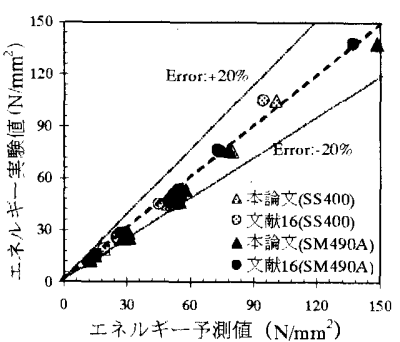

(a) 単軸応力

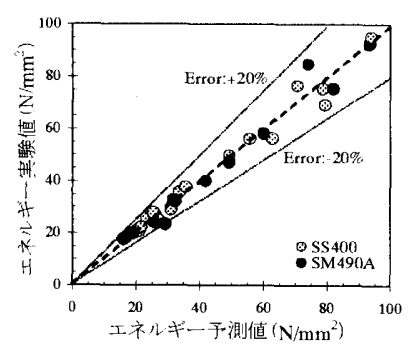

(b) 多軸応力及び複合交番
図19 履歴吸収エネルギー 図17(a)〜(d)に、複合交番載荷シリーズの履歴曲線を示す。実験值 と予測值の対㐫は良好である。

\section{5 .2 累積歪及び履歴吸収エネルギ一の比較}

骨格曲線に打ける累積歪や履歴吸収エネルギーは、鋼材の損傷を 表す指標として用いられる。ここで、試験終了時における肾格曲線 上の果積相当柾について、履歴モデルによる予測值と実験值の比較 
を行う。図18(a)(b)に結果を示す。図中単軸応力シリーズには、文献 16による予測值も併せて示している。いずれのシリーズにおいても、 実験值と予測值はほぼ一致していることが分かる。また、試験終了 時までの全履歴において吸収された歪エネルギーについて、履歷モ デルによる予測值と実験值の比較を行う。ここでのエネルギーは応 力を歪について積分して求めたため、単位体積当りのエネルギ一の 次元になっている。罒19(a)(b)に結果を示す。予測值と実験値の対応 は良好である。

\section{5. 結論}

複合応力下における応力歪関係の基本的な特性について検討する ため、SS400 材及び SM490A 材の中空円筒状試験片を製作し、軸方 向載荷及び洺じり載荷試験を実施した。載荷経路は、(1)軸方向応力 若しくはせん断応力の一方を作用させる単軸応力シリ一ズ、(2)軸方 向又はせん断方向のうち一方に初期応力を導入し、他方の応力を変 動させる多軸応力シリーズ、(3)軸方向応力とせん断応力を交互に作 用させる複合交番載荷シリーーズの3グルー.ブとした。得られた知見 は以下のとおりである。

1) 計測データを相当応力-相当昰に換算し、複合応力下の履歴曲線 を求め、これを骨格曲線、バウシンガ--部、弹性除荷部に分割し た。抽出した情格曲線は、引張試験による忍力歪関係によって近 似できた。また、バウシンガー部には載荷経路による影響が認め られ、多軸応力シリ-ーズ及び複含交番載荷シリーズでは、単軸応 カシリーズほどバウシンガー一部が軟化しない傾问が確認された。

2) 文献 15 で提案された復歴モデルを複合忍力に適用できるように 拡張した。提案した履歴モデルでは、舴格曲線は等方硬化則に従 い、バウシンガー部の降伏曲面は搪大・移動・縮小が考虐されて いる。

3) 提案した履歴モデルにより、実験における履歴曲線の形状を最好 に近似できた。しかし、歪の軌跡を予測する上で大きな䛊差が生 じるケースも見られた。履歴モデルに基いて愲格曲線におりる累

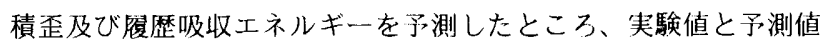
は概将一致した。

本研究では、基礎的な実験デー夕を得ることに力点をおいている。 実験で採用された載荷経路は限定的なものであり、本履歷モデルの 適用範囲については検討の余地がある。また、既往の履歴モデルと の対応についても今後の課題である。

\section{謝辞}

加力装置及び試験片製作に際し、横浜国立大学青木博文教授に御 助言頂きました。ここに記して篤く御礼申し上げます。

\section{参考文献}

1) Hill, R.: Mathematical Theory of Plasticity, Oxford Univensity Press, Oxford University, 1950

2) Prager, W: A New Method of Analyzing Stresses and Strains in Work-Hardening Plastic Solids, Journal of Appl. Mech. pp.493-496, 1956.12

3) Ziegler, H.: A modification of Prager's Hardening Rule, Quartery of Applied Mathematics, Vol.17, pp.55-65, 1959

4) Morz, Z: On Description of Anisotropic Work-hardening, Jour. Mech. Phys. Solids, Vol.15, pp.163-175, 1967
5) Iwan, W. D.:On a Class of Models for the Yielding Behavior of Continuous and Composite Systems, ASME, Journal of Applied Mechanics, pp.612-617, 1967.9

6) Petersson, H. and Popov, E. P.: Constitutive Relation for Generalized Loadings, Proc. of ASCE, Vol.103, No.EM4, pp.611-627, 1977

7) Popov, E. P. and Petersson, H.: Cyclic Metal Plasticity: Experiments and Theory, Proc. of ASCE, Vol.104, No.EM6, pp.1371-1388, 1978

8) 加藤勉、秋山宏、山内泰之：鋼材の応力一ひぎみ履歴曲線に関する実験則、 日本建築学会大会学術講演梗概集、構造系、pp.937-938, 1973.10

9) Yoshitura Yokoo, Tsuneyosi Nakamura, Toshiro Komiyama and Yasuo Kawada: Non-Stationary Hysteretic Uniaxial Stress-Strain Relations of a Wide-Flange Stress, 日本建築学会論文報告集, No.259, pp.53-63, 1977.9

10) 原伸次、青木博文 : 鋼素材の繰返し応力度一䄳度関係の数式表示に関寸る 研究、日本建築学会大会学術講演梗概集、c-1, pp. 495-496, 1997.9

11）藤本盛久、青榑文、米沢房雄、新倉茂男: 構造用金属材料の力学的挙動 に及ぼすひずみ履歴の影響(その2. 圧縮ひずみ履歴およびせん断ひずみ履 歴の影響)、日本建築学会論文報告集、No.254,pp.51-60, 1977.4

12) 山田稳、过文三：鋼材の応力一歪関係に関する研究（Ｉ：等方+移動硬化 モデル）、日本建築学会構造系論文集、No.270, pp.17-22, 1978.8

13) 藤本盛久、橋本秀、中込忠男、山时丈富 : 構造用鋼材の多軸方向応力状態 における緤り返し応力ーひずみ関係（その1 繰り返し力を受ける鋼構造 溶接接合部の破壊挙動に関寸る研究）、日本建築学会構造系論文集、No.356, pp.93-101. 1985.10

14) 加藤勉、秋山宏 : 構造部材の而力（その 4)、日本建築学会論文報告集、 No.151, pp.15-20, 1968.9

15) 11 田哲、今枝知子、岡田健：バウシンガー効果を考虑した構造用鋼材の籣 潔な履歴モデル、日本建築学会構造系論文集、No.559,pp.225-2.32, 2002.9

16) Chung, K.S.. Matsumoto, Y. and Yamada, S.: Study on the Constitutive Relation of Structural Steel under Multi-axial Stress; part 1 . In case of Uni-axial Loading Paths, the $2(x) 4$ pacific structural steel conference, $2004.3^{2}$

17) Krieg, R.D. and Krieg, D.B. : Accuracies of Numerical Solution Methods for the Elastic-Perfectly Plastic Model, Transactions of ASME, Joumal of Pressure Vessel Technology. pp.510-515, 1977.11

(2004年：9月101.原稿受理，2004俰11月5日採用決定） 